\title{
田
}

\section{COMUNICAÇÃO PÚBLICA: UM DIREITO HUMANO EM CONEXÃO COM O SERVIÇO SOCIAL}

\author{
Public communication: a human right in connection with social work
}

\author{
Kênia Augusta Figueiredo*
}

\begin{abstract}
RESUMO
Esse artigo tem por objetivo refletir sobre a conexão entre a Comunicação Pública e o Serviço Social a partir de referenciais teórico-metodológicos e de pesquisa de campo. Com singularidade e formas próprias a Comunicação Pública se fundamenta nos direitos humanos e atribui o protagonismo a população por meio do exercício da cidadania havendo, portanto, um diálogo necessário entre as áreas visto o projeto ético político do Serviço Social. Essa transversalidade, em especial nas políticas sociais colabora em essência para o fortalecimento da democracia e para a noção de direito de cidadania. Sob este aspecto, de reconhecimento de si e para si é que o Serviço Social, por meio de suas intervenções técnico-operativas e da função pedagógica alicerçada na dimensão teórico-metodológica e ético-politica tem muito a contribuir para a construção de uma cultura hegemônica dos trabalhadores com o suporte técnico político da Comunicação Pública.
\end{abstract}

\section{PALAVRAS CHAVES}

Comunicação pública. Direito humano. Cultura. Serviço Social.

\begin{abstract}
ABSTRAT
This article aims to reflect on the connection between Public Communication and Social Work based on theoretical and methodological references and field research. With singularity and its own forms the Public Communication is based on human rights and attributes the protagonism to the population through the exercise of citizenship, therefore, there is a necessary dialogue between the areas, considering the political ethical project of Social Work. This transversality, especially in social policies, contributes in essence to the strengthening of democracy and to the notion of the right of citizenship. In this respect, recognition of self and for itself is that Social Work, through its technical-operative interventions and the pedagogical function based on the theoretical-methodological and ethical-political dimension, has much to contribute to the construction of a hegemonic culture of the workers with the political technical support of Public Communication.
\end{abstract}

\section{KEYWORDS}

Public communication. Human right. Culture. Social work.

Submetido em: 30/9/2018.

Aceito em: 26/11/2018.

\footnotetext{
* Assistente Social. Doutora em Comunicação pela Universidade de Brasília. Professora do Departamento de Serviço Social da Universidade de Brasília (UnB, Brasília, Brasil). Campus Universitário Darcy Ribeiro, Instituto Central de Ciências (ICC) Norte - Asa Norte, Brasília (DF), CEP.: 70910-900. ORC ID: <https://orcid.org/00000002-1401-8215>. E-mail:<figueiredo.kenia@gmail.com>.
}

DOI 10.22422/temporalis.2018v18n36p162-177 


\section{INTRODUÇÃO}

Esse artigo tem por objetivo refletir sobre a conexão entre a Comunicação Pública e o Serviço Social, destacando o potencial de contribuição que essa transversalidade possui para o fortalecimento da democracia ${ }^{1}$, por meio da construção de uma cultura hegemônica dos trabalhadores ${ }^{2}$. Trata-se, portanto, de uma reflexão que se referencia no conceito clássico de Comunicação Pública que a compreende como um direito humano e no projeto ético-político da profissão.

O $10^{\circ}$ Congresso Brasileiro de Assistentes Sociais (CBAS), realizado no Rio de Janeiro (RJ), em 2001 é referenciado na história recente do Serviço Social como um marco do debate sobre comunicação e Serviço Social ${ }^{3}$. Ao longo deste período alguns assistentes sociais e jornalistas presentes nas entidades de representação da categoria têm abordado vários temas tais como a mídia e a questão social, a utilização das tecnologias da informação, o trabalho de comunicação e mobilização social junto ao público atendido pelo Serviço Social e ainda, sobre o processo político de democratização da comunicação no país. Trata-se, sem dúvida, de reflexões exigentes, visto os desafios inerentes à interdisciplinaridade e as transformações societárias propiciadas inclusive pela velocidade tecnológica que circunda a comunicação na contemporaneidade.

${ }^{1} \mathrm{O}$ conceito de democracia aqui empregado se sustenta em Coutinho (2000, p. 129) que afirma que, na modernidade, ocorre uma profunda articulação entre cidadania e democracia, sendo o melhor conceito que expressa a democracia a cidadania, uma vez que democracia implica também no acesso e na apropriação aos bens socialmente produzidos por parte dos indivíduos. Ambas decorrem de processos históricos, pois a cidadania e a democracia não são obtidas pelos indivíduos de forma determinada, por períodos indeterminados, e sim resultam de uma luta permanente, travada pelas classes sociais e segmentos subalternizados, implicando, assim, um processo histórico de longa duração. Portanto, a democracia tem relação não só com as modificações da política, mas também com a economia e com a questão social, sendo minimalista a concepção liberal quando aborda que a democracia tem relação apenas com as regras formais que definem os processos eleitorais. Coutinho colabora ainda com a compreensão deque a democracia é um valor universal, pois “[...] deve ser entendida não como algo que se esgota em determinada configuração institucional, mas sim como processo. [...] A democracia é soberania popular, é construção de uma comunidade participativa, é igualdade".

${ }^{2} \mathrm{~A}$ compreensão acerca de uma cultura hegemônica dos trabalhadores se referencia na definição de Gramsci sobre hegemonia. Para Gramsci, há um momento em que os homens deixam a condição de egoísticopassional para elevarem-se ao ético-político, ao nível da consciência universal. A esse momento Gramsci denomina catarse que deve ser entendida como a passagem da estrutura à superestrutura, da necessidade à liberdade, sendo o momento em que o individuo se transforma em ser social e se forma o bloco histórico que permite integrar dialeticamente as forças da esfera econômica com as expressões culturais e a participação dos trabalhadores excluídos. É na sua luta por uma sociedade socialista que Gramsci desenvolve uma estratégia denominada de Guerra de Posição. Ela se fundamenta na ideia de uma contra-hegemonia "[...] criada pela organização da classe trabalhadora e pelo desenvolvimento das instituições e da cultura da classe operária" (CARNOY, 1986, p. 110). Nesse sentido, faz-se necessário compreender o que é cultura popular em Gramsci. Para ele, o popular é determinado econômico e socialmente pela divisão social das classes. No entanto, a cultura popular se distingue não pelo fator artístico, nem por sua origem histórica, mas por seu modo de conceber o mundo e a vida, em contraste com a sociedade oficial capitalista. O popular não está determinado apenas pela cultura nacional-local, mas possui uma universalidade própria, desconhecendo fronteiras.

30s marcos históricos da categoria no debate sobre comunicação já receberam vários registros por meio d algumas publicações. Nos valemos especialmente para esta afirmativa da publicação sobre a Política de Comunicação do Conjunto CFESS-CRESS editada pela gestão Atitude Crítica para avançar na luta (2008-2011) (CONSELHO FEDERAL DE SERVIÇO SOCIAL; CONSELHOS REGIONAIS DE SERVIÇO SOCIAL, 2010). 


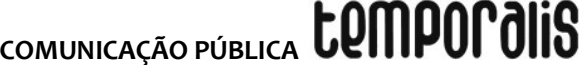

No entanto, longe de se intimidarem frente a um leque de desafios, o que se percebe seja por meio da pesquisa realizada sobre a comunicação pública junto aos usuários dos Centros de Referência de Assistência Social (Cras) 4 e na participação em eventos da categoria no último período é que os assistentes sociais estão cada vez mais instigados a aprofundar sobre os processos comunicativos junto ao público atendido e buscam perceber os impactos e as possibilidades advindos das inovações tecnológicas junto a estes e no que tange a relação entre comunicação e cultura.

Afinal, este tempo como cunhou Santos (2005) de turbocapitalismo e globalitarismo, de veloz avanços tecnológicos, de flexível acumulação do capital - combinação da extração de mais-valia e trabalho morto - e da informação e conhecimento como os principais insumos de uma ordem produtiva altamente tecnologizada e que se converte em valor cultural, nos remetem a situações que esperam dos trabalhadores sociais: análises, propostas e atitudes criticas.

Para o conjunto CFESS/CRESS55a defesa da democratização da comunicação, o direito à informação e a liberdade de expressão são princípios articulados à defesa dos direitos humanos e da emancipação política e se apresentam por meio da publicação de documentos, bem como pela participação, dentre outras, no Fórum Nacional de Democratização da Comunicação (FNDC) que tem resistido e enfrentado esse período de ataque frontal ao Estado democrático de direito, com campanhas eloquentes como "Calar Jamais"- campanha contra violações à liberdade de expressão e concomitante tem realizado denuncias e manifestado em defesa dos direitos humanos das pessoas oprimidas, sendo ainda tímido o enfrentamento ao mercado publicitário e televisivo que inflige costumeiramente direitos de crianças, mulheres, negros, gays, lésbicas, travestis, transexuais, pessoas obesas e outros segmentos. Contudo, a direção da categoria é clara: “Nossa Escolha é a ResisTência6"!!!!

É comum ouvirmos com muita sonoridade a mídia reivindicando seu direito a liberdade de expressão. Mas, é preciso pensar sobre como os/as assistentes sociais pensam o direito a liberdade de expressão dos/as usuários/as das políticas sociais em que atuam e em como é trabalhado com estas pessoas o direito a informação, o direito a comunicação, a liberdade de expressão e a emancipação política.

Com base nessas questões importa buscar aproximações que alarguem nossas possibilidades de respostas às questões elencadas. Nesse sentido, um conceito da comunicação que é a Comunicação Pública tem nos possibilitado um diálogo com as dimensões teórico-metodológico, ético-político e técnico-operativo construídas historicamente pelo Serviço Social. Embora seja um conceito em construção, servindo para

\footnotetext{
${ }^{4}$ Trata-se de uma pesquisa qualitativa, estruturada e de campo sobre a comunicação pública junto aos usuários dos Centros de Referência de Assistência Social (Cras), realizada no período de março de 2014 a janeiro 2015, nas cinco regiões do Brasil. Foram ouvidos gestores, técnicos (assistentes sociais e psicólogos), usuários e representantes de usuários nos conselhos municipais da política de Assistência Social. Os municípios visitados foram: Rubiataba (GO), Tobias Barreto (SE), São Gabriel (RS), Santarém (PA), Belo Horizonte (MG).

${ }^{5}$ A expressão "conjunto CFESS-CRESS" refere-se à unidade política e administrativa do Conselho Federal de Serviço Social (CFESS) e os Conselhos Regionais de Serviço Social (CRESS).

${ }^{6}$ Campanha do Conjunto CFESS/CRESS para o dia do assistente social, lançada no primeiro semestre de 2018.
} 


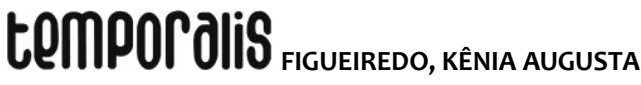

abordar desde a regulação dos meios de comunicação, bem como o fim do monopólio no Brasil, a Comunicação Pública pode ser identificada como o direito a comunicação transversal às políticas publicas sociais.

Com singularidade e formas próprias a Comunicação Pública se fundamenta nos direitos humanos e atribui o protagonismo a população por meio do exercício da cidadania. Pode, portanto ser compreendida "[...] como um processo de comunicação que se instaura por meio de um atendimento público qualificado, mediado por agentes públicos, inseridos nas políticas sociais, no âmbito do Estado" (FIGUEIREDO, 2017, p. 17)7. Portanto, diz respeito ao trabalho e a função pedagógica do assistente social.

A Comunicação Pública é um recurso de trabalho que qualifica a linguagem, um instrumento de trabalho do assistente social pouco aprofundado pela categoria, mas igualmente importante principalmente visto ser este período de informação fácil, com múltiplas possibilidades, mas de pouca densidade nas comunicações.

Importa qualifica-la como um direito humano fundamental com vistas ao fortalecimento da democracia por sê-la um valor instrumental estratégico (NETTO, 1996); um valor universal (COUTINHO, 2000) e ainda de acordo com Gramsci (2001) serem as transformações construídas de forma gradativa, através de reformas profundas, não se tratando de um mero reformismo melhorista, que vise apenas melhorar o capitalismo. Daí que cada informação compreendida como um instrumento para a inclusão política, econômica e social dos/as trabalhadores/as que atendemos é de vital importância para a vida dessas pessoas e para a resistência.

Comunicar é preciso! E pensar "[...] o direito humano à comunicação é resgatar uma unidade dialética entre a dimensão humana e técnica da comunicação" (GOMES, 2007, p. 158). Isso nos atualiza enquanto categoria e colabora para nos mantermos coerentes com o projeto ético político do Serviço Social.

\section{COMUNICAÇÃO PÚBLICA: CAMPO PARA A CONTRUÇÃO DE UMA CULTURA COMUM}

De acordo com Gomes (2007) os direitos humanos são uma das mais complexas buscas da civilização moderna e que traz consigo "[...] uma memoria de liberdade e barbárie, de guerras como formas para se chegar à paz e de violência para se alcançar o nudo da dignidade humana" (GOMES, 2007, p. 48). Trata-se de uma trajetória societária em que se constrói um consenso de reconhecimento de que a pessoa humana é o fim de tudo. Essa autora entende que essa afirmação histórico-social está contida nas fundamentações teóricas e na positivação contidas nas Constituições, Pactos, Tratados e Convenções de conteúdos obrigatórios para os Estados. Mas, contudo é importante compreendê-la como histórica, portanto inacabada, estando em permanente construção, sujeita às correlações de forças e à dinâmica da luta de classes.

\footnotetext{
7 Extraído da palestra "O/A assistente social e os processos comunicativos: por uma contra-hegemonia dos subalternos”, proferida no evento realizado pelo Núcleo de Assistentes Sociais de Poços de Caldas/Conselho Regional de Serviço Social-MG, em 13/06/2017.
} 


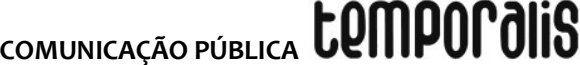

Assim, considerando a realidade dinâmica é importante categorizar a comunicação como um direito humano para que o próprio direito humano reconheça a comunicação como um direito fundamental, um devir social a ser considerado sob as influências ideológicas, econômicas, políticas, culturais e sociais. Ou seja, o reconhecimento da comunicação como um direito humano engloba a compreensão dos direitos civis, políticos e sociais.

Ao assumir a comunicação como um direito humano reconhece-se algumas particularidades que precisam ser evidenciadas. A primeira delas é que a comunicação historicamente foi traduzida como transferência de dados e informações: um ser que informa e outro que ouve. Foi somente a partir do século 20, mais precisamente na segunda metade é que a comunicação ganhou uma proximidade com os direitos humanos ampliando seu significado e alcance. É preciso, no entanto compreender que essa aproximação não se deu de forma mágica, mas a partir de muitos processos de luta e resistência no mundo.

Existe um documento que expressa de forma contundente a aproximação da comunicação como um direito humano, bem como a sua relação com a democracia. Esse documento, escrito a partir da $19^{\text {a }}$ Conferência Geral, realizada em Nairóbi (Quênia), em 1976 foi lançado em 1980, sendo no Brasil três anos depois, recebeu o nome de "Um mundo e muitas vozes - comunicação e informação na nossa época ou Relatório MacBrid”. Foi produzido pela Unesco - órgão das Nações Unidas que trata da educação, ciência e cultura a partir do trabalho de uma comissão ampla, com representação de vários países inclusive da América Latina, sendo presidida pelo jurista e jornalista irlandês Sean MacBride ${ }^{8}$. Importa considerar que a base de toda discussão sobre a comunicação estava associada ao seu papel para o fortalecimento da democracia, refletindo assim uma leitura da conjuntura da época visto o cenário político, econômico e social mundial, em especial na América Latina mergulhada no imperialismo norte americano e em ditaduras militar.

Aqui no Brasil a luta pelo reconhecimento da relação entre comunicação e democracia, portanto como um direito humano se expressa na Constituição Federal de 1988 (CF88) por meio da garantia de: liberdade de opinião, de pensamento, de expressão, difusão de informação, comunicação, propaganda, meios de comunicação, além de ser transversal a várias áreas. $\mathrm{O}$ artigo $5^{\circ}$, inciso XXXIII, assegura a todos o direito de receber dos órgãos públicos informações de seu interesse particular, ou de interesse coletivo ou geral, sendo estas prestadas no prazo da lei, sob pena de responsabilidade, exceto aquelas cujo sigilo seja necessário à segurança da sociedade e do Estado. Trata-se, portanto, de um direito

\footnotetext{
${ }^{8}$ É importante assinalar, conforme destaque do prof. Murilo Ramos em palestra, no dia 16 de abril de 2013, que este documento foi deliberado em circunstâncias políticas em que estavam reunidos representantes de três blocos: os Estados Unidos e seus aliados; a União Soviética e seus aliados, e um grupo de países que se declaravam 'não alinhados' - este último com inclinações a se aliar ao bloco liderado pelos soviéticos. Compuseram a Comissão Internacional para o Estudo dos Problemas da Comunicação os seguintes representantes: Sean MacBride (presidente - Irlanda), Elie Abel (EUA), Hubert Beuve-Méry (França), Elebe MaEkonzo (Zaire), Gabriel García Márquez (Colômbia), Serguei Losev (URSS), Mochtar Lubis (Indonésia), Mustapha Masmoudi (Tunísia), Michio Nagai (Japão), Fred Isaac Akporuaro Omu (Nigéria),Bogdan Osonik (Iugoslávia), Gamal El-Oteifi (Egito), Johannes Pieter Pronk (Holanda), Juan Somavia (Chile); Boobli George Verghese (Índia) e Betty Zimmerman (Canadá). (ORGANIZAÇÃO DAS NAÇÕES UNIDAS PARA A EDUCAÇÃO, A CIÊNCIA E A CULTURA, 1983, p. 482-483.)
} 


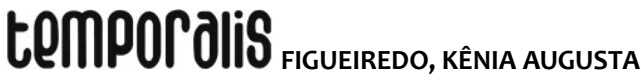

social de “[...] quarta geração [...]" (RAMOS, 2005, p.1), que requer transparência e fidedignidade nas informações veiculadas pelo Estado, por meio de seus organismos.

Desta forma, é no campo da contra-hegemonia que emerge o direito à comunicação. "Um direito que se refere à liberdade individual e ao direito humano fundamental da palavra, da expressão" (LIMA, 2010, p.21). Se a comunicação entre os sujeitos sociais tem sua origem por uma necessidade ontológica, o debate acerca da comunicação como um direito humano advém da complexificação da sociedade, emergindo de lutas como: as lutas inglesas (1215-1689), norte-americanas (1776-1787) e as francesas (1789-1848), quando a questão da comunicação aparece no grupo de direitos fundamentais, tais como a liberdade religiosa, liberdade de opinião, pensamento e de expressão, liberdade de imprensa, liberdade de reunião e associação. No entanto, é com os críticos da industrialização e do tecnicismo da comunicação do pós-guerra que aflora a ideia de constituir o direito relacionado à comunicação com dimensões internacionais, uma vez que "[...] o fio de relações que determinam e condicionam quem pode ou não efetivamente exercer a comunicação ultrapassa a necessidade ontológica, e chega aos movimentos de dominação" (GOMES, 2007, p. 156).

É neste campo dos direitos humanos que o conceito de comunicação pública tem sido gestado e construído. Para Brandão (2009), entre os diversos entendimentos sobre o conceito, existe um ponto comum em sua compreensão que se refere a ser a comunicação pública um "[...] processo comunicativo que se instaura entre o Estado, o governo e a sociedade com o objetivo de informar para a construção da cidadania" (BRANDÃO, 2009, p. 9).

Zémor (2005) colabora com a ideia de a comunicação pública trabalhar na perspectiva da socialização da informação como meio de construção da cidadania, bem como contribuir para assegurar à relação social o afloramento do sentimento de pertencer ao coletivo e de tomada de consciência do cidadão enquanto sujeito. Esta contribuição aponta na direção de a comunicação pública se constituir por dentro das políticas sociais, como parte integrante. Trata-se de pensar a comunicação pública, conforme aponta Sardinha (2012), como um "[...] modelo teórico-operativo, como um serviço público tão fundamental como são os serviços de saúde" (SARDINHA, 2012, p.12).

O sentido da comunicação pública nas instituições públicas, para Zémor (2005), deve estar associado aos papéis de regulação, proteção e/ou de antecipação do serviço público, por meio de atribuições como: i) informar (levar ao conhecimento, prestar conta e valorizar); ii) ouvir as demandas, as expectativas, as interrogações e o debate público; iii) contribuir para assegurar a relação social (sentimento de pertencer ao coletivo, tomada de consciência do cidadão enquanto sujeito); iv) acompanhar as mudanças, tanto as comportamentais quanto as de organização social .

Nessa perspectiva, a democracia é um valor instrumental estratégico, não um instrumental dentre outros, mas, por ser

[...] o único que, na sua operacionalização, antecipa um modo de comportamento social genérico, que, no desenvolvimento do processo revolucionário, através de 


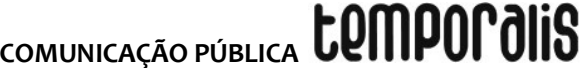

rupturas sucessivas, tenderá, pela prática política organizada e direcionada pela teoria social, a permear todas as instâncias da vida social (NETTO, 1990, p. 86).

A política, “[...] essência da democracia [...]" (RAMOS, 2007, p.31), para ser revolucionária, uma vez que a liberdade e a igualdade não são um estado natural, mas um ideal a se perseguir, deve estar vinculada à luta contra a hegemonia da classe dominante e deve incluir, como aponta Carnoy (1986), o desenvolvimento de uma contra-hegemonia, baseada em valores e em uma cultura efetivamente democrática.

Nesse sentido, Williams (2011) considera que a cultura é uma reação geral a uma mudança geral e significativa nas condições de nossa vida em comum. Entende que a comunicação passou a ter uma centralidade a partir de 1914, e não é por acaso que regularmente usamos, na atualidade, tanto a ideia das 'massas' e as ideias consequentes: civilização de massa, democracia de massa, comunicação de massa. Por trás desse conceito, existe o interesse de ofuscar a democracia de classes ou mesmo de dar aos trabalhadores a ideia de que estes ameaçam a cultura, por serem identificados como uma turba, por parecerem ingênuos e com vulgaridade de gosto e hábitos. Para ele, a relação com o receptor é algo a ser aprofundado, uma vez que o problema não está na técnica utilizada, mas na intenção. Esse seria o verdadeiro perigo para a democracia, pois toda teoria de massa depende essencialmente de uma minoria de alguma forma explorando uma maioria. Neste caso, a única desigualdade importante, ou até mesmo concebível, é a desigualdade do ser. Daí que uma cultura comum não é uma cultura igual e, ainda, uma cultura comum não pode colocar restrições absolutas à participação em qualquer de suas atividades, pois é na práxis política que os subalternos podem expressar aspirações para além de seus pleitos pessoais, sendo a cultura algo vivo e sempre em transformação.

Martin-Barbero (2013) considera que o processo comunicativo deve ser visto em sua totalidade e de forma contínua, ou seja: produção, recepção, meio e mensagem. Para o autor ao considerar todo o processo pelo qual se dá a comunicação é possível perceber que, mesmo com a alienação própria do capitalismo e da sociedade dos meios, o receptor não está impossibilitado de filtrar as mensagens que se dá por meio de mediações, uma vez que a comunicação e a cultura são categorias intercambiáveis.

A vinculação entre as categorias comunicação e cultura proposta pelo autor decorre se entendemos a cultura como uma dimensão dos processos sociais e que diz respeito à sociedade como um todo, podendo ela ser produto ou produtora, tanto no que tange a manutenção de concepções e de formas de organização quanto para a transformação da sociedade. Importa também considerar que em uma sociedade de classes existem manifestações diferentes da classe dominante, que não passam por suas instituições e ocorrem independentemente delas. Trata-se da cultura popular que também se legitima em decorrência do próprio reconhecimento dos dominantes. Neste sentido, a cultura deve ser compreendida como uma construção histórica e um produto coletivo da vida humana, sendo que em uma sociedade de classes o resultado cultural produzido e em constante transformação, se faz da relação entre as classes, embora seus benefícios e controle não sejam compartilhados igualmente.

No entanto, as manifestações culturais não se limitam apenas às relações sociais de que são produto, pois possuem dinâmica própria e são, em essência, criativas. Daí o 


\section{tempordilis}

reconhecimento de Martin-Barbero (2013) de que as mediações são um campo fértil das apropriações e resignificados dos receptores em relação à mensagem produzida. Para ele é no terreno das mediações que se dão as articulações entre práticas de comunicação e movimentos sociais, visto que elas integram cultura e comunicação na processualidade do cotidiano, por ser a cultura vivida na sua dinamicidade comunicativa. Daí que na relação entre a produção da mensagem para o receptor a "[...] mediação seria o pano de fundo onde as manifestações comunicacionais orquestram as tramas culturais" (BASTOS, 2008, p. 86).

Nesse sentido, importa ressaltar que comunicação pública deve ser considerada para além da comunicação governamental, entendida como a comunicação que ocorre em um espaço temporal, subjugada a interesses de grupos políticos, formado por fluxos de informações e comunicações. Importa também considerar, de acordo comMatos (2006), o contexto atual de centralidade da mídia, bem como as transformações na tecnologia e no mercado, que colaboram, inclusive, para o deslocamento progressivo do polo públicocidadão para o polo público-consumidor. Daí ser importante o destaque da autora de que a "[...] comunicação pública contém a comunicação política e não o seu inverso [...]" (MATOS, 2006, p. 72), exatamente para que não se perca a perspectiva de totalidade em um período em que as disputas de poder contribuem para novas formas de interação política.

\section{SERVIÇO SOCIAL E AS PRÁTICAS COMUNICATIVAS: UM DIÁLOGO NECESSÁRIO}

É no campo das políticas sociais e assistenciais, que são a síntese de múltiplas determinações e desenvolvem funções primordiais no mundo capitalista, tais como: social, econômica e política e, na concretização da tarefa reguladora do Estado na vida social que o Serviço Social realiza suas intervenções. Deste lugar, o assistente social tem acesso a dois mundos complementares que convivem em tensão uma vez que sendo "[...] a questão social desigualdade é também rebeldia [...]”, como afirmou lamamoto (2001, p. 28). Tratase, portanto de uma posição muitas vezes ambígua, uma vez que reproduz, por meio de uma mesma atividade interesses opostos. Atende, portanto, tanto os interesses do capital como as necessidades sociais impostas aos trabalhadores, sendo que só se pode fortalecer um dos lados pela mediação do seu oposto.

Desta forma, o Serviço Social interfere na reprodução material da força de trabalho e no processo ídeo-político dos indivíduos sociais, contribuindo para produzir e reproduzir o trabalhador e sua família, bem como abrir possibilidades aos subalternos de uma releitura da realidade. Iamamoto (2001) considera ser este o produto do trabalho do assistente social que também é mediado pelas condições e relações de trabalho, bem como pela dimensão ético-política.

Para realizar seu trabalho em condições de contribuir para impulsionar formas democráticas e ampliar possibilidades de acesso, de acordo com lamamoto (2001), o assistente social utiliza dois instrumentos: o conhecimento, enquanto base teóricometodológica e a linguagem. Por meio dos fundamentos teóricos metodológicos o profissional realiza uma leitura da realidade e decide sobre as bases de sua intervenção. Ou seja, para intervir é necessário conhecer a realidade social que se dá a partir da investigação 


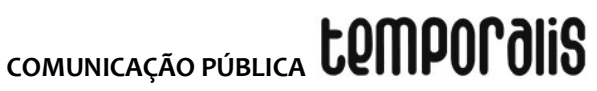

da realidade, o que pressupõe um domínio do método de pesquisa e de princípios teóricos que trarão clareza ao objeto, bem como sobre a utilização dos recursos adequados ao encaminhamento da questão apresentada.

A linguagem, o segundo instrumento de trabalho apontado por lamamoto e Carvalho (2003), desde 1982, está obviamente vinculada à escolha das bases teóricas-metodológicas e ético-política que sustentam o conhecimento. Entretanto, ao longo da trajetória do Serviço Social tem-se produzido pouco conhecimento acerca deste instrumento, embora a comunicação esteja presente cotidianamente no trabalho do assistente social e constitua parte das atribuições profissionais, conforme indica a lei que regulamenta a profissão ${ }^{9}$.

As experiências apontadas pela pesquisa sobre comunicação pública junto aos usuários dos CRAS nos mostram que o uso da linguagem no exercício profissional tem requerido dos profissionais uma maior compreensão a este respeito, como é o caso apresentado por uma assistente social, em Belo Horizonte, no decorrer de uma entrevista ${ }^{10}$.

Ela nos narrou que em um determinado momento foi avaliado pela equipe técnica, a partir de escutas na comunidade, a necessidade de propiciar reflexões acerca da questão sobre a utilização de drogas. Tomada a decisão de realizar um evento com esta temática deflagraram um processo de organização com vistas a garantir que toda a comunidade tivesse a oportunidade de conhecer mais a este respeito. Conseguiram com esforço, segundo a entrevistada, um carro de som para circular na região. Fizeram cartazes, avisaram em todos os espaços que puderam e se empenharam muito, afinal partia de uma necessidade percebida pela comunidade e pelos técnicos. Chegado o dia da reunião a surpresa ficou a cargo da total ausência. Ninguém compareceu. Afinal, onde haviam errado? A conclusão da equipe é que diante de um convite tão amplo para um assunto tão complexo ninguém se sentiu à vontade para comparecer. Como ela mesma disse:

Colocamos um carro de som passando em toda a comunidade, convidando os moradores a participar de uma oficina sobre drogas, mas ninguém veio. Concluímos que havíamos, na verdade, era "avisado" desde a Igreja, ao tráfico, aos usuários de drogas, a todo mundo (Técnica 1 do Cras na região Oeste, Belo Horizonte (MG), 2014).

Outra técnica também comentou sobre o desafio do uso da linguagem oral na justa medida, ou seja, aquela capaz de entrar em ressonância com as preocupações, com a situação, com a cultura e com o vocabulário do usuário.

O básico do nosso trabalho ele passa por uma transformação e transformação se faz através de informações, né? Nós temos a dificuldade de repassá-las. [...] Acho que a falha está na gestão dos técnicos no diálogo do dia-a-dia com o usuário mesmo. [...] Essa questão da comunicação vai muito da fala do técnico com o usuário e como são pessoas em extrema vulnerabilidade social e a questão de pouco estudo fica muito complicado porque às vezes o técnico vai muito técnico

\footnotetext{
${ }^{9}$ Lei 8662/93 - Dispõe sobre a profissão de assistente social e dá outra providências no artigo $4^{\circ}$, incisos II, III, V, VIII, IX,XI e artigo $5^{\circ}$, inciso IV.

${ }^{10} \mathrm{O}$ caso apresentado não se trata de uma particularidade. Por meio da pesquisa apuramos situações de esvaziamento e ausência da comunidade em eventos articulados e realizados pelas equipes técnicas, sendo que em alguns destes a própria equipe tem refletido sobre a relação das ausências com as formas de comunicação.
} 
e aí não usa esse cuidado e é a questão que a gente tem falado nos grupos e me colocam mais usuária do que técnica porque às vezes falo muito a linguagem popular para que eles entendam. (Técnica do Cras2. Tobias Barreto (SE), 2014)

Uma questão também detectada pela pesquisa sobre comunicação pública junto aos usuários dos CRAS foi sobre a necessidade dos trabalhadores sociais quanto a materiais de comunicação de apoio, seja um folder, faixas, murais, sites e outros. De acordo com as/os técnicas/os nos Cras, é muito difícil "[...] transmitir o que somos na Assistência Social para os usuários e fazer com que o usuário reflita e saiba que ele está acessando um serviço de assistência social, e não um programa de outra secretaria" (Técnica do Cras1, de Tobias Barreto (SE), 2014). Assim, para qualificar essa interlocução, as/os técnicas/os produzem informações do tipo institucional, que orientam sobre a estrutura, as atribuições e o funcionamento do Cras e da Assistência Social, indicando os direitos e deveres do usuário. Todos os Cras visitados possuem material gráfico, que são sempre pensados pela equipe e em não tendo um/a profissional que arrisque na confecção recorre-se a um familiar ou uma pessoa conhecida, com habilidades em designer gráfico, prestando um trabalho voluntário. A reprodução do material gráfico conta com o apoio do nível central da instituição para a reprodução.

A busca por compreender sobre a relação do Serviço Social com a comunicação tem nos mostrado que precisamos contemporanizar e aprofundar sobre os limites e as possibilidades da comunicação no exercício profissional do assistente social, não se tratando de desassociar a questão das dimensões teórico-metodológicas, técnicooperativas e ético-político da profissão, mas de conhecer as particularidades que circundam este tema.

Nesta perspectiva, optamos pela compreensão de que a comunicação é um construto e nasce da necessidade da interação entre os homens, sendo por meio da linguagem e do trabalho que o ser humano constitui o social e forma historicamente a si mesmo. Neste sentido, a linguagem é trabalho, uma vez que traz a marca da intervenção transformadora dessa espécie, uma vez que as palavras e as mensagens não existem prontas na natureza. Portanto, o uso da linguagem no trabalho dessa categoria profissional tem um valor de uso ${ }^{11}$.

A linguagem oral tem sido a mais utilizada pelos assistentes sociais na relação com os usuários, mas também se recorre à linguagem por meio de gestos, expressões corporais e faciais, palavras e símbolos e, às vezes, do silêncio. Sem dúvida o lócus de atuação e as demandas pertinentes ao trabalho do assistente social são determinantes à utilização pela profissão da linguagem oral, uma vez que este tipo de linguagem decorre da existência de

\footnotetext{
${ }^{11}$ Para Marx um bem possui dois tipos de valores: valor de uso e valor de troca. O valor de uso é medido pelo trabalho concreto, ou seja, do trabalho que depende da habilidade humana. Já o valor de troca da mercadoria está relacionada a quantidade de tempo que o trabalhador gasta para produzi-la. Se um indivíduo é um alfaiate, sua profissão produz o valor de uso: ele sabe fazer roupas. E, roupas tem serventia (valor de uso). Para Marx, o trabalho é útil ou concreto. Não é o consumidor que dá utilidade a uma mercadoria, mas o produtor. O consumidor apenas reconhece a mercadoria como útil ou não. Para Marx, o valor era, portanto, determinado no âmbito da produção e não da circulação. Cada mercadoria possuía seu próprio valor de uso. Mas, todas elas foram produzidas pelo uso da força de trabalho. Então, o trabalho serve para igualar todas as mercadorias. A utilidade não pode ser quantificada, mas o tempo dispendido na fabricação do bem pode ser quantificado.
} 


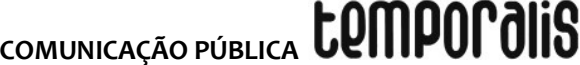

uma coletividade, de uma dinâmica entre a fala e a escuta, que só pode ser praticada a partir de ao menos dois sujeitos.

A linguagem oral reproduz som, texto e imagem, mas, diferentemente da linguagem na sociedade midiatizada, ela possibilita aproximações objetivas e subjetivas, o que possibilita uma troca que incide diretamente na cultura, visto sua natureza comunicativa que dialoga sobretudo com o imaginário e com as emoções. Ou seja, a linguagem oral colabora tanto para uma maior confiança nas relações entre o usuário, o profissional e a instituição, quanto para potencializar a função pedagógica do assistente social, conforme verificamos por meio das entrevistas junto aos usuários nos Cras quando indagamos sobre como se sentiam em relação ao atendimento nos Cras. A maioria deles nos informou que obtiveram êxito naquilo que demandaram, mas que para tal o trabalho dos assistentes sociais foi muito importante. Alguns abordam que recorrem diretamente ao profissional para obterem orientações e sugestões sobre muitos assuntos que nas palavras de muitos deles "nem sempre tem a ver com o Cras". Registramos ao longo de várias entrevistas, por meio da fala e de gestos, a confiança e agradecimento ao trabalho desenvolvido pelo profissional.

Domingues (2010), em referência a Mcluhan, aponta que a linguagem oral proporciona uma experiência estética e essencialmente da ordem do temporal. Ou seja, a linguagem oral possibilita a variação de entonações, a diversificação de gestos, movimentos e criação de expressões, sendo que tudo o que foi falado é efêmero e dependente da memória. Além disso, a palavra dita é altamente específica e local e pode existir uma dúzia de palavras para designar o mesmo, como também uma única para exprimir sentidos variados. A palavra remete para a sutileza da distinção e está ligada aos aspectos práticos da vida cotidiana, estando carregada de significado emocional e pessoal, pois cada conteúdo e entoação desperta diferentes matizes de emoções e significados, além de poder se falar de maneira mais incoerente e muito coloquial, importando assim saber quais são as palavras certas, a ordem de as dizer, a entoação e os gestos.

Outra dimensão da comunicação que tem se apresentado para o Serviço Social diz respeito à sociedade midiatizada. Ainda que estejamos culturados pela sociedade dos meios ou pela indústria cultural, estamos experimentando processos comunicativos que ganharam velocidade e espaço com a presença de participantes sociais nas práticas e processos antes restritos à indústria cultural, como afirma Braga (2012). Nesse contexto, já não é tão simples diferenciar pontos iniciais e pontos de chegadas das mensagens, a produção e a recepção como instâncias separadas, sendo a circulação transformada em um lugar no qual produtores e receptores se encontram em relações bem complexas de ofertas e reconhecimento. Assim, o receptor - já visto em outros tempos como passivo e acrítico, não só quebrou a lógica da fidelização, mas ainda faz seguir adiante as reações ao que recebe. Nesta perspectiva, a inserção cultural do receptor é compreendida como uma mediação fundamental entre a sociedade e as proposições da mídia de massa e se põe, historicamente, como espaço da ação de resistência.

Para alguns sociólogos e antropólogos, citados por Martin-Barbero (2013), em pesquisa sobre a cidade de Buenos Aires (Argentina), há uma produção de sentidos construída nos movimentos sociais e nos bairros, uma vez que a base da cultura política já não se faz somente no âmbito tradicional de organização dos trabalhadores, mas se dá também em 
espaços do bairro, como a escola, o café, as bibliotecas e clubes, visto as alterações no mundo do trabalho. Por meio da pesquisa nos CRAS, constatamos que a maioria dos entrevistados está vinculada ao mundo do trabalho por atividades de prestação de serviços com vínculos informais, como é o caso dos trabalhadores domésticos que prestam serviços recebendo seus honorários por meio de diárias, não estando estes vinculados no geral a nenhuma organização sindical. Suas referências e fontes de informação são construídas no cotidiano, na relação com os vizinhos e parentes seja durante o trajeto da casa para o ponto de ônibus e ou no percurso do transporte coletivo em direção ao trabalho e também por meio do rádio.

Em consideração a esta reorganização social, os pesquisadores argentinos e MartinBarbero (2013) consideraram que um elemento que tem corroborado com a constituição dessa cultura popular são os mediadores, indicados por eles como os profissionais que atuam "[...] nas instituições locais fazendo a conexão entre as experiências dos setores populares e outras experiências do mundo intelectual e das esquerdas" (BARBERO, 2013, p. 273). Na perspectiva de Gramsci (2001) podemos compreender a mediação referida pelos pesquisadores como uma práxis pertinente aos intelectuais em colaboração ao processo de emancipação dos subalternos e denominado por ele de catarse: o momento em que os homens deixam a condição de egoístico-passional para elevarem-se ao éticopolítico, ao nível da consciência universal.

\begin{abstract}
A Catarse deve ser entendida como a passagem da estrutura à superestrutura, da necessidade à liberdade, é o momento em que o individuo se transforma em ser social, no que se produz o sentido unitário da sociedade e se forma o bloco histórico que permite integrar dialeticamente as forças da esfera econômica com as expressões culturais e a participação das massas excluídas (SEMERARO,1999, p. 156).
\end{abstract}

No bairro, vai se desenvolvendo uma nova institucionalidade, um tecido social em que avida cotidiana possibilita às pessoas a construção de um a gente, já que no trabalho, muitas vezes, elas são apenas a/o empregada/o. Aqui elas se constituem e se transmitem, por meio de suas famílias, vizinhos/as e amigos/as. Dessa forma, de acordo com as reflexões de Martin-Barbero (2013) a necessidade de partidos ${ }^{12}$ para a população de um modo em geral deixa de ser interessante posta à dissociação da política à vida cotidiana, uma vez que eles se encontram mais interessados com a tomada do Estado ou com sua permanência no poder.

Tradicionalmente, as esquerdas consideram o cotidiano um obstáculo à consciência do que como ação politicamente consequente. No entanto, no cotidiano se pode refletir sobre as leis do mercado, o consumo, o uso do tempo, o corpo, o habitat, a consciência do possível para cada vida. Como afirma Yazbek (2003, p. 67), “[...] os subalternos correspondem a uma realidade caracterizada pelo lugar que ocupam nas relações sociais [...]”, sendo que o

\footnotetext{
${ }^{12}$ Em suas reflexões Martin-Barbero (2013) se posiciona que na atualidade as pessoas conseguem construir uma identidade coletiva mais movidos pelas questões nos bairros do que pelos partidos políticos, pois para ele, em sua maioria, os partidos estão mais preocupados em se manter no poder a encampar as lutas dos trabalhadores. Interessa ao autor apontar para uma questão presente na América Latina que diz respeito à representatividade dos partidos políticos e que de fato merece muitos estudos e reflexões. No entanto, somos partícipes da compreensão de que na forma como o Estado está estruturado na América Latina não é possível prescindirmos dos partidos políticos, o que não quer dizer não sermos críticos a eles.
} 


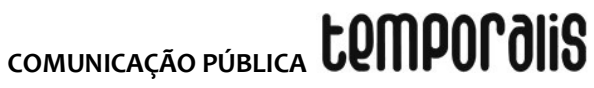

mundo dos dominados não se encontra separado do mundo dos dominadores. Eles possuem um ponto de contato, que se dá exatamente onde se exerce o domínio. Do ponto de vista cultural, são realidades que se interpenetram sem haver território definido.

Nesse sentido, o ponto de partida para a constituição de um povo não tem relação com a unidade dada por um sujeito, mas por uma pluralidade de posições de sujeitos, que começam a estabelecer entre si certo grau de solidariedade, ou melhor, hegemonia. De acordo com Laclau (2006) "[...] uma certa particularidade assume a função de uma totalidade, uma universalidade [...]" (LACLAU, 2006, p. 24) sendo daí que decorre a hegemonia. Ou seja, a partir de uma cadeia equivalencial, em que várias questões de interesse particular vão ganhando uma dimensão coletiva. Nessa perspectiva, a globalização e o mercado são os significantes que articulam a construção sociolinguística de uma realidade compatível com a ideologia neoliberal que se impõe pela virtualidade. $\mathrm{E}$ é também a essa realidade que a categoria dos assistentes sociais precisa considerar.

\section{CONSIDERAÇÕES FINAIS}

A partir dessas considerações podemos perceber que a comunicação pública junto com o Serviço Social pode contribuir para a construção de uma cultura hegemônica dos trabalhadores e do fortalecimento da democracia, uma vez que de acordo com Brandão (2009, p. 27), na comunicação pública está presente a orientação básica de fortalecimento da democracia e a noção de direito de cidadania, uma vez que o conceito de comunicação pública visa a "dar vozes aos que não têm voz", ou melhor, àqueles que têm voz, mas são muito pouco ouvidos. Busca resgatar o sentido social da comunicação, com base nos ideais de uma comunicação libertadora, articulada a uma visão humanística. "Nas raízes deste paradigma, está a mistura de rebeldia, idealismo e a dor da resistência, que marcaram os anos 1960 a 1980 na América Latina, e que forjaram a construção de um campo de conhecimento ideologicamente engajado" (BRANDÃO, 2009, p. 29). Portanto, a comunicação pública está comprometida com o aumento da consciência dos cidadãos acerca de seus direitos de cidadania, vindo a colaborar no combate ao clientelismo, ao patrimonialismo e às relações de subserviências.

Nessa perspectiva, a comunicação pública pode ser operada como uma metodologia de trabalho interdisciplinar, transversal à política social, a fim de oportunizar a ampliação e a potencialização de uma verdadeira política de cidadania, como ocorreu em Guarulhos (SP), segundo a pesquisa de Rego e Pinzani (2013) sobre as beneficiárias do Programa Bolsa Família. Afirmam os autores, ao apresentarem alguns casos em que houve investimento na formação cidadã, que o Programa Bolsa Família ganhou nova qualidade democrática e nova qualidade cívica.

De acordo com Benjamim (1986), a superestrutura se modifica mais lentamente. Em sociedades com alta densidade de informação, a produção não implica apenas na questão econômica, mas diz respeito também aos processos relacionais e ao campo social/cultural. Por isso, a reflexão sobre o fato ocorrido em maio de 2013 merece ser evidenciada, uma vez que elucida muitas fragilidades que podem ser, a tempo, enfrentadas, desde que se reconheça o potencial articulador e de resistência deste segmento populacional. 
Gramsci (2001), ao considerar que o Estado abrange a sociedade civil, compreende também que o desenvolvimento de uma nova hegemonia incide sobre o mesmo, sendo que o Estado opera como um educador, uma vez ter poder para direcionar a criação de um novo tipo ou nível de civilização. Para tal a democracia é determinante para o desenvolvimento da sociedade e diz respeito diretamente à cidadania coletiva que se constrói no processo de luta, no interior da prática social, sendo por meio dessas a afirmação da identidade político-cultural, sendo "[...] hegemonia (é) sinônimo de cultura no seu sentido amplo e, sobretudo de cultura em sociedades de classes" (CHAUÍ, 2003, p. 90).

Sob este aspecto, de reconhecimento de si e para si, é que o Serviço Social, por meio de suas intervenções técnico-operativas e da função pedagógica alicerçada na dimensão teórico-metodológica e ético-politica tem muito a contribuir para a construção de uma cultura hegemônica dos trabalhadores. É sem dúvida por meio da linguagem oral e outros instrumentos de comunicação que se engendra a função pedagógica do assistente social, sustentada na atualidade pelos princípios do projeto ético político. Essa função, presente desde os primórdios da profissão precisa ter na formação profissional introduções sobre o direito à comunicação e na atuação profissional requerer da estrutura de Estado condições de trabalho que assegurem as tarefas do agente público que são: informar por dever, assegurar uma pedagogia às mensagens, incluir a comunicação em todo o processo de atendimento e, especialmente contribuir para conferir sentido à vida coletiva. Isso é construir na superestrutura processos no campo social, comunicacional e cultural que visam o fortalecimento da democracia, noção de direito de cidadania e de consciência de classe.

\section{REFERÊNCIAS}

BASTOS, Marco Toledo de Assis. Do sentido da mediação: às margens do pensamento de Jesús Martín-Barbero. Porto Alegre: Revista FAMECOS, nº 35, 2008.

BENJAMIM, Walter. A obra de arte na era de sua reprodutibilidade técnica: magia e técnica, arte e política: ensaios sobre literatura e história da cultura. São Paulo: Brasiliense, 1986. (Obras escolhidas, volume 1).

BRAGA: José Luiz. Circuitos versus campos sociais. In: MATTOS, Maria Ângela; JANOTTI JUNIOR, Jeder; JACKS, Nilda (Org.). Mediação \& Midiatização. Salvador: EDUFBA; Brasília: Compós, 2012.

BRANDÃO, Elizabeth. Conceito de comunicação pública. In: DUARTE, Jorge. Comunicação pública: estado, mercado, sociedade e interesse público. 2. ed. São Paulo: Atlas, 2009.

BRASIL. Constituição da República Federativa do Brasil. Brasília: Senado Federal, 1988.

BRASIL. Presidência da República. Lei no. 8662/93. Regulamenta a profissão de Assistente Social. Disponível em: <http://www.cfess.org.br/arquivos/legislacao_lei_8662.pdf>. Acesso em: 9 set. 2018.

CARNOY, Martin. Estado e Teoria Política. São Paulo: Papirus, 1986. 
CHAUÍ, Marilena. Cultura e democracia. 10. ed. São Paulo: Cortez, 2003.

COUTINHO, Carlos Nelson. Contra a corrente: ensaios sobre democracia e socialismo. São Paulo: Cortez, 2000.

DOMINGUES, José Antônio Domingues. O paradigma mediológico: Debray depois de Mcluhan. Livros LabCom. (Série Estudos em Comunicação). Covilhã, 2010. Disponível em: <http://www.labcom-ifp.ubi.pt/livro/33>.

FIGUEIREDO, Kênia Augusta. Comunicação pública e assistência social: um estudo sobre os processos comunicativos nos Centros de Referência de Assistência Social/Cras. 2016. Tese (Doutorado em comunicação)-Universidade de Brasília, Faculdade de Comunicação, Brasília (DF), 2016.

FIGUEIREDO, Kênia Augusta. O/A assistente social e os processos comunicativos: por uma contra-hegemonia dos subalternos. Poços de Caldas: Núcleo de Assistentes Sociais de Poços de Caldas; Belo Horizonre: Conselho Regional de Serviço Social-MG, 13 jun. 2017. Mimeo.

GOMES, Raimunda Aline Lucena. A comunicação como direito humano: um conceito em construção. Dissertação (Mestrado em comunicação)-Universidade Federal de Pernambuco, CAC. Comunicação, Recife, 2007.

GRAMSCI, Antonio. Cadernos do Cárcere. Volumes 3 e 4. Edição e tradução: Carlos Nelson Coutinho. Coedição: Luiz Sérgio Henriques e Marco Aurélio Nogueira. Rio de Janeiro: Civilização Brasileira, 2001.

IAMAMOTO, Marilda V. O Serviço Social na Contemporaneidade: trabalho e formação profissional. 5. ed. São Paulo: Cortez, 2001.

IAMAMOTO, Marilda Villela; CARVALHO, Raul de. Relações Sociais e Serviço Social no Brasil. 15. ed. São Paulo: Cortez, 2003.

LACLAU, Ernesto. Inclusão, exclusão e a construção de identidades. In: Amaral, A.C.; BURITY, J. (Orgs.). Inclusão social, identidades e diferenças: perspectivas pósestruturalistas de análise social. São Paulo: Annablume, 2006.

LIMA, Venício A. Liberdade de expressão $x$ liberdade de imprensa: direito à comunicação e a democracia. São Paulo: Publisher Brasil, 2010.

MARTIN-BARBERO, Jesús. Dos meios às mediações: comunicação, cultura e hegemonia. 7. ed. Rio de Janeiro: Universidade Federal do Rio de Janeiro, 2013.

MATOS, Heloiza Helena Gomes. Comunicação Política e Comunicação Pública. Revista Organicom, São Paulo: USP, ano 3, n. 4, 2006. 


\section{tempordils}

NETTO, José Paulo. Transformações societárias e Serviço Social. Serviço Social e Sociedade, São Paulo: Cortez, n. 50, 1996.

NETTO, José Paulo. Democracia e transição socialista: escritos de teoria e política. Belo Horizonte: Oficina de Livros, 1990.

RAMOS, Murilo César. Comunicação, direitos sociais e políticas públicas. In: MARQUES DE MELO, J.; SATHLER, L. direitos à comunicação na sociedade da informação. São Bernardo do Campo: Unesp, 2005.

RAMOS, Murilo César; SANTOS, Suzy dos. Políticas de comunicação: busca teórica e práticas. São Paulo: Paulus, 2007.

REGO, Walquiria Leão; PINZANI, Alessandro. Vozes do Bolsa Família: autonomia, dinheiro e cidadania. São Paulo: Unesp, 2013.

SANTOS, Milton. Por uma outra globalização: do pensamento único à consciência universal. 6. ed. São Paulo: Record, 2005.

SARDINHA, Antônio Carlos. Comunicação, controle social das políticas públicas e os desafios para a Comunicação Pública nos conselhos gestores de saúde. Revista e-Com, v. 5, n. 1, 2012.

SEMERARO, Giovanni. Cultura e educação para a democracia: Gramsci e a sociedade civil. Petrópolis: Vozes, 1999.

WILLIAMS, Raymond. Cultura e sociedade: de Coleridge a Orwell. Petrópolis: Vozes, 2011. YAZBEK, Maria Carmelita. Classes subalternas e assistência social. 4. ed. São Paulo: Cortez, 2003.

ZÉMOR, Pierre. La comunication publique. Tradução resumida do livro: Dra. Elizabeth Brandão. Paris: PUF, 2005. (Coleção Que sais-je?). 